Perspective

\title{
China's South-to-North Water Diversion Project Empowers Sustainable Water Resources System in the North
}

\author{
Giri R. Kattel ${ }^{1,2, * \mathbb{D}}$, Wenxiu Shang ${ }^{1} \mathbb{D}$, Zhongjing Wang ${ }^{1,3,4, *}$ and John Langford ${ }^{2}$ \\ 1 Department of Hydraulic Engineering, Tsinghua University, Beijing 100084, China \\ 2 Water, Environment and Agriculture Program (WEAP), Department of Infrastructure Engineering, \\ The University of Melbourne, Melbourne, VIC 3010, Australia \\ 3 State Key Lab of Hydro-science and Engineering, Tsinghua University, Beijing 100084, China \\ 4 State Key Lab of Plateau Ecology and Agriculture, Qinghai University, Xining 810016, China \\ * Correspondence: gkattel@unimelb.edu.au (G.R.K.); zj.wang@tsinghua.edu.cn (Z.W.)
}

Received: 10 May 2019; Accepted: 3 July 2019; Published: 9 July 2019

\begin{abstract}
Global freshwaters are severely depleted. Provision of improved water infrastructure technologies and innovation can address challenges posed by water shortages to environmental sustainability. China's South-to-North Water Diversion Project has generated extensive debates over sustainability of water resources system in the northern drier region, which faces severe water scarcity hindering ecosystems, agriculture, industries and livelihoods. Some arguments extend the views that large infrastructure projects can have negative implications for biodiversity conservation and ecosystem goods and services. However, this study strengthens the opposite view, as such projects would resolve increasing environmental challenges northern China has been facing over many decades due to severe water shortages. The project empowers connectivity among individuals, community, and organizations that the sustainability of goods and services such as energy, irrigation and water supply are perceived, and livelihoods and the standard of peoples' living is improved. A resilient, robust and adaptive water infrastructure framework can overcome the challenges of water shortages by meeting a long term social, economic and environmental goals for water resources systems in northern China. Such framework can also identify the thresholds of change and the threats associated with environmental sustainability.
\end{abstract}

Keywords: South-to-North Water Diversion Project; northern China; sustainable water resources system; thresholds

\section{Introduction}

Global freshwaters generate important goods and services for social and economic development. Freshwater ecosystems goods and services are however severely depleted during the 21st century due to population growth, urbanisation, climate change and poor governance [1-3]. Provision of improved water infrastructure technologies and innovations are thought to be important strategy to address water shortages and environmental sustainability issues particularly in drier regions.

China's South-to-North Water Diversion Project (SNWDP) has received extensive debates and interests on environmental sustainability among scientific community within and outside China. Over the years, the water-intensive economic development in northern China is hindered by severe water shortages $[4,5]$. The northern region, where more than 150 million people live, has faced a dramatic reduction as high as 150 billion $\mathrm{m}^{3}$ of groundwater reserves over recent decade, causing a significant decrease in the water supply across Beijing, Tianjin and Hebei [6,7]. Groundwater reserves have played a vital role in protecting the environments against droughts over millennia [8]. Over-extraction of the 
surface water resources from the Yellow River has also significantly altered downstream flows and the capacity of sediment flushing to the East China Sea [9]. Low flows have led to drying out of water courses of the Hai River and wetlands for extensive periods raising a critical question of environment protection and the future sustainability of the socioeconomic development of the region [10].

SNWDP is thought to fuel next phase of productivity growth that meets growing water demands, and resolve increasing environmental challenges including over-extraction of surface water resources and reduction of groundwater reserves in the region [11]. Large-scale infrastructure including the SNWDP, are often viewed as opportunities and a pursuit of practical solutions to the pressing sustainability challenges such as identifying environmental vulnerability and adaptation through integration of natural and social disciplines [12-14]. Such projects empower connectivity among individuals, community, and organizations that the sustainability of goods and services such as energy, irrigation and water supply are perceived and livelihoods and standards of living as well as education and health outcomes of people are improved [15-17].

However, there are some anxieties that large-scale infrastructure projects may often stand as drawbacks to sustainability impacting on biodiversity conservation and ecosystem goods and services (e.g., fisheries) and may also increase debts and economic burdens among consumers including increased water pricing $[18,19]$. Rapid climate warming can exacerbate the conditions further such as aging infrastructure and reducing water use efficiencies [20]. The safety of water transferred through the conveyance channel and issues of potential water pollution is threatened by sudden chemical accidents and source modifications in the catchment [21]. Increased spatial and temporal variability of anthropogenic inputs including nutrients (total phosphorous, total nitrogen), toxic metals (e.g., cadmium) and organic pollutants $\left(\mathrm{NH}^{+}-\mathrm{N}\right)$ to rivers across the larger cities such as Beijing and Tianjin have been found as significant hazards to the transferred water [22]. More reliable and accurate modelling and forecasting of water quality and hydrological variables are also the major concerns [23].

Yet, there are studies showing that SNWDP empowers sustainability of water resources system by creating better environments for biodiversity and ecosystems, improving surface water-ground water connectivity, mitigating climate change and increasing water use efficiency in the northern dry region $[24,25]$. Studies have also begun to show that the eastern and middle routes of SNWDP, which are already in operation (Figure 1), have consolidated market-oriented water allocation system, reduced coal energy consumption and improved communications among stakeholders and regional socioeconomic conditions of more than 100 million people in Jiangsu, Anhui, Shandong, Hebei and Tianjin [26-29]. The middle route alone has transferred 8 billion $\mathrm{m}^{3}$ of water to Beijing since 2014 and supported 21.5 million people annually. About 73 percent of tap water in the northern urban areas comes from SNWDP. The project has contributed to environmental flows in major river systems in the region. The channeled 467-million $\mathrm{m}^{3}$ water has replenished wetlands and reservoirs and improved water quality. The groundwater in Xushui District has risen $0.96 \mathrm{~m}$ [30]. Hebei and Henan, the two important provinces for agriculture in China, are benefitted the most with production of 59 million tons of agriculture goods annually due to improved irrigation [31]. The drinking water quality in the region has improved within the range of national standard (II) for consumption [32]. It has been said that effective energy management can reduce costs and enhance sustainability [33]. The use of renewable energy has contributed to enlarge $95,000 \mathrm{~km}^{2}$ riparian areas [25,34]. After the launch of SNWDP, the consumption of coal energy in the region has also reduced [30]. These outcomes are indicators of inevitable gains of environmental sustainability including climate change mitigation in the region. 


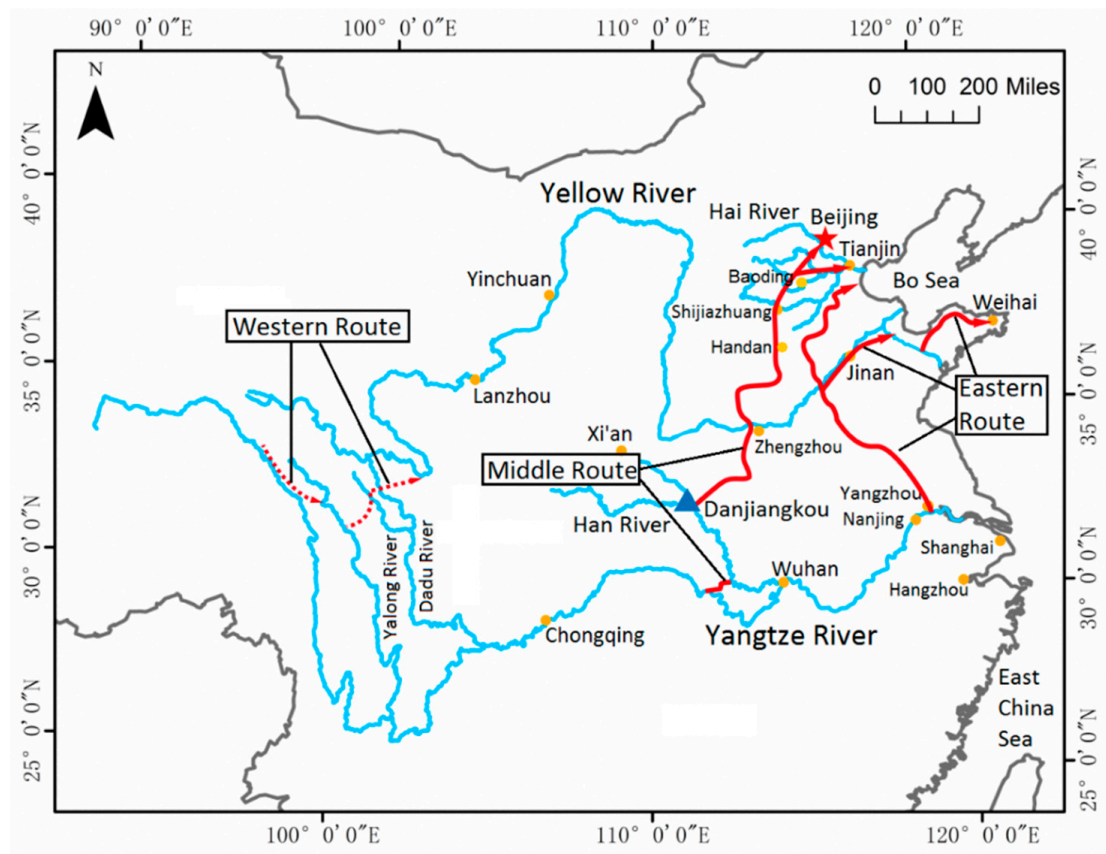

Figure 1. China's South-to-North Water Diversion Project (SNWDP). The routes are shown with red (solid and dotted) lines. The eastern route project along Beijing-Hangzhou Grand Canal aims to alleviate water shortages in Jiangsu, Anhui, Shandong, Hebei and Tinjin. The Phase I of the Eastern Route Project supplies $8.8 \times 10^{9} \mathrm{~m}^{3}$ water in total, out of which, $1.1 \times 10^{9} \mathrm{~m}^{3}$ water is supplied to Shandong (Jinan, Qindao, Zhaozhing and Weihai). Phase I of the middle route project supplies $9.5 \times 10^{9} \mathrm{~m}^{3}$ water from Han River (tributary of the Yangtze River) to Beijing, Tianjin and Hebei. The western route project, yet to be commenced, will divert water from the upper Yangtze River, dammed reservoirs in the Tongtian River, Yalong River and Dadu River (all are tributaries of the Yangtze River) to Qinghai, Gansu, Ninxia, Shaanxi, Shanxi provinces, and the Inner Mongolia Autonomous Region.

However, despite the all positive signs, targeting a resilient, robust and adaptive water resources system to meet a long term social, economic and environmental goals of large-scale water diversion projects requires a comprehensive understanding of environmental change and vulnerability, a careful assessment of drivers and a real time implementation of the environmental monitoring program [20]. The comprehensive assessment on the use of sustainability models and frameworks is often considered as powerful tool for better understanding of the large-scale water delivery projects [16,35]. In this study, a conceptual framework has been developed on the imminent threats posed by rapid environmental change such as the depletion of water resources in northern China. The framework is thought to provide better prospective for sustainable water resources system in SNWDP by assessing various thresholds of environmental change in the region. We argue that a comprehensive understanding of the human-environment interactions and the response of ecosystems to changing socioeconomic conditions under large water delivery projects is useful to identify associated thresholds and to address key sustainability measures for water resources systems in the region.

\section{Water Resources System Context in Northern China and the Role of SNWDP in Sustainability}

Water shortages in northern China are projected to be 30 billion $\mathrm{m}^{3}$ by 2030, causing $\$ 20$ billion financial losses due to low grain production [36]. The increased rates of water use between 2011 and 2016 in three river basins, Huang (65\%), Huai (74\%), Hai (94\%) and over-extraction of groundwater resources in the region have indicated to severe water shortages [10,36,37]. Larger cities such as Beijing, Hebei and Tianjin, in particular have suffered the most (Table 1), for example at a cost of yearly 500 billion Yuan (about $\$ 73,000$ million) $[38,39]$. 
Table 1. Comparison among the three routes of SNWDP adopted from $[11,40]$.

\begin{tabular}{|c|c|c|c|}
\hline & Eastern Route (ERP) & Middle Route (MRP) & Western Route (WRP) \\
\hline $\begin{array}{c}\text { Water transfer } \\
\text { capacity (billion } \mathrm{m}^{3} \text { ) }\end{array}$ & 14.8 & 13 & 17 \\
\hline Division of phases & 3 & 2 & 3 \\
\hline Length $(\mathrm{km})$ & 1467 (phase I) & 1432 (phase I) & $>100$ (tunnel) \\
\hline Dam construction & NA & $\begin{array}{l}\text { Existing dam elevating } \\
\text { from current } 162 \text { to } \\
176.6 \mathrm{~m} \text { in height }\end{array}$ & New dams $>200 \mathrm{~m}$ in height \\
\hline Water transfer & Pumping stations & Flow by gravity & $\begin{array}{l}\text { Flow by gravity and } \\
\text { pumping stations }\end{array}$ \\
\hline $\begin{array}{l}\text { Areas receiving } \\
\text { water }\end{array}$ & $\begin{array}{l}\text { Jiangsu, Anhui, Shandong, } \\
\text { and Hebei Provinces and } \\
\text { Tianjin Municipality }\end{array}$ & $\begin{array}{l}\text { Henan, Hebei Provinces } \\
\text { and Beijing, Tianjin } \\
\text { Municipalities }\end{array}$ & $\begin{array}{l}\text { Qinghai, Gansu, Ninxia, } \\
\text { Shaanxi, Shanxi Provinces } \\
\text { and Inner Mongolia } \\
\text { Autonomous Region }\end{array}$ \\
\hline Purpose of water use & $\begin{array}{l}\text { Agricultural, domestic, } \\
\text { industrial, and navigation }\end{array}$ & $\begin{array}{l}\text { Domestic, industrial, and } \\
\text { agricultural }\end{array}$ & $\begin{array}{l}\text { Environmental, agricultural, } \\
\text { domestic, and industrial }\end{array}$ \\
\hline $\begin{array}{l}\text { Estimated costs } \\
\text { billions (\$US) }\end{array}$ & 9 & 10 & 37 \\
\hline State of project & $\begin{array}{c}\text { Phase I was completed and } \\
\text { began operation in } 2013\end{array}$ & $\begin{array}{l}\text { Phase I was completed } \\
\text { and began operation in } \\
2014\end{array}$ & Under preliminary study \\
\hline
\end{tabular}

Until recently, about 18 billion $\mathrm{m}^{3}$ water in total is diverted from the eastern route project (ERP) and the middle route project (MRP) of the SNWDP benefitting the significant residential and ecological communities by bringing economic prosperity and improved environmental conditions in the north $[25,36,41,42]$. The MRP alone has improved water self-purification capacity in Beijing by reducing $1 \times 10^{8} \mathrm{~m}^{3}$ groundwater extraction as well as by refreshing natural lakes, alleviating droughts and water logging capacity [11]. The project has stimulated regional economic development by creating employment opportunities, making better transportation network and facilities, expanding irrigation schemes, electricity and aquaculture, recreational fishing and tourism industries as well as controlling flood hazards (Table 2). This is because, the SNWDP has adopted regulation of environmental flow regime, water pollution control, and conservation and management of water, soil and biota, which is expected to maximize the China's regulation of environmental redlines for freshwater systems [27,43-46]. Despite these measures, urban and industrial water demands and irrigation, energy and environmental protection together with challenges of groundwater recharge continue to increase complexity in environmental-hydrological-socioeconomic interactions and vulnerability to sustainable water resources system (Figure 2). As a result, the future of China's water resources system is likely to show imbalanced supply and demand for agriculture and general population due to increased land use and climate change interactions in the region [47]. Such a capital-intensive project is also blamed as biased economic analysis, leading to cost overruns with construction delays and extinction of local biodiversity and reduced ecosystem-based goods and services [38,48].

However, China's industrial growth and increasing water demand have been maintained through sustainable water allocation, and water use efficiency strategies that have assisted restoration of aquatic biodiversity and ecosystem goods and services in the region [27,49]. Provisions have also been made for development of wastewater treatment plants and construction of artificial wetlands in the region. A long-term water quality monitoring program has been set up for wetland ecosystems restoration and groundwater replenishment in Hebei, Tianjin and Beijing [26,36,50]. Recent paradigm shift in China's water reforms policy by creating large-scale infrastructure projects like SNWDP and by using a holistic water resources development (environment-ecosystem-hydrology) approach (Figure 2) has brought fundamental change in the quality of the people's life in the region [36]. It has been argued that absence of integration of strategies in resource assessments and policy-making can lead to poor performance of 
water use efficiencies. Integration of strategies related to climate, land-use, energy and water, together with resource assessments, can improve governance and sustainability of water resources [51].

Table 2. Current and projected (2030 AD) eco-environmental benefits (in market values) of the eastern route of SNWDP [52].

\begin{tabular}{ccc}
\hline \multirow{2}{*}{ Benefits } & \multicolumn{2}{c}{ Net Benefits (Billion Yuan RMB) } \\
\cline { 2 - 3 } & $\mathbf{2 0 1 0}$ & $\mathbf{2 0 3 0}$ \\
\hline Agricultural ecosystems & $1,127,129$ & $1,623,366$ \\
Forest ecosystems & $1,066,865$ & 279,534 \\
Urban greeneries & 396,267 & 552,306 \\
Overall eco-environmental benefits & $2,070,167$ & $2,848,878$ \\
\hline
\end{tabular}

Note: The analysis of economic benefits is based on market value assessment using shadow engineering approach of the observed data and relevant literature.

\section{Sustainability Measures and Thresholds of Change in Water Resources System}

China needs the use of better approaches and strategies of infrastructure policies including recognizing the thresholds of environmental change and sustainability of water resources system [40]. Studies suggest that an improved environment, better socioeconomic conditions and peaceful living are some of the key measures of sustainability [13]. However, when a society experiences rapid socioeconomic transformations, this will lead to increased human-environment interactions, and vulnerability of sustainability due to threshold crossings [16,53,54]. The policies adopting to sustainability measures are becoming useful for increasingly urbanized societies in China to meet future food and water security goals $([55,56]$. Integration of natural and social sciences within the framework of traditional (cultural) values are effective for water resource management and societal peace [56]. It has been argued that incorporating better designs and management principles in infrastructure planning reduces investment risks, enhances robustness and adaptive capacity of the society [20].

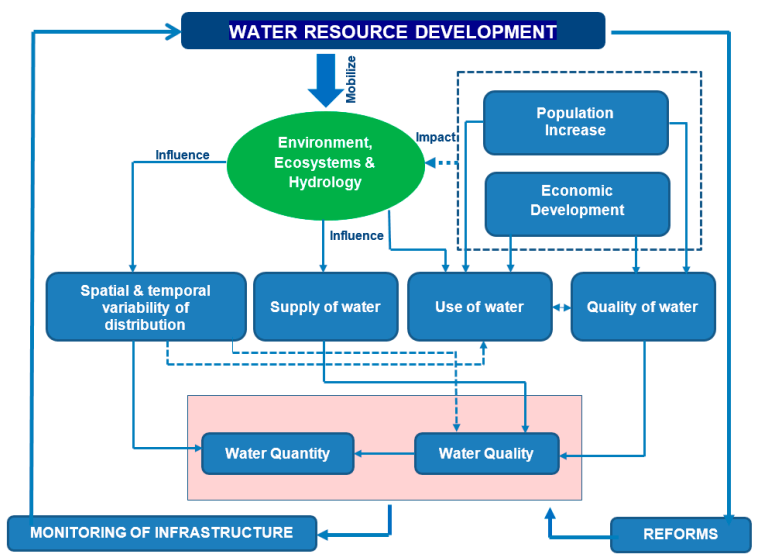

Figure 2. Water resources development framework under complex interactions of demographic, socioeconomic, environmental, hydrological and ecological drivers o SNWDP. The water resource development (outer framework) mobilizes environment, ecosystems and hydrology. The interactions (inner framework) directly influence spatial and temporal variability in distribution patterns and supply of water, and consequently cause water quantity and quality. Demographic and socioeconomic development directly impact on extraction of water and water quality. Poor water quality increases shortages of healthier water for drinking. Dotted lines denote relatively weaker influence (adopted from [57]. The water resources development is achieved through regular monitoring of both infrastructure and water resources and providing subsequent strategies for water resources reforms to improve water quantity and quality in the northern region.

However, large water infrastructure projects are also costly, often requires substantial number of human displacements, and causes biodiversity and fisheries losses leading to reduce societal resilience 
and peace [20]. For instance, about 10 million people were displaced from the Danjaiangkou reservoir (the source of SNWDP) catchment, which caused significant human stress. Further, the people living on the outskirts of the reservoir are exposed to diseases caused by water stagnation [36] and nonpoint water pollution from intensive agriculture [40]. The engineering work, shielding of tunnels, quality control of prestressed concrete cylinder pipes, and construction of large canals are thought to be risky and make negative impacts on sustainability [58]. Besides, about $22 \%$ of water diverted from the Han River (tributary of the Yangtze) to MRP is reported to have affected the environmental flow regimes of the Han River, reducing sustainability [58].

Sustainability of the river systems in the southern section of SNWDP has also improved. The flow regulation has been better managed by establishing the Xinglong Water Conservancy Project. The amount of diverted water to the project has been cut down during dry seasons and used as environmental water [11]. The integration of principles of water resources, societal values, ecology with infrastructure designs and operations has been valued to satisfy the multiple objectives of sustainability in the region. Societal conflicts have been reduced by compensating the displaced families for houses, economic trees and production equipment and supporting them to settle down elsewhere [11]. It has been argued that water resource infrastructure principles when integrated with environmental requirements including river flows and habitats reduce stresses among people and enhance sustainability $[11,14,20]$. China prioritizes an integration of infrastructure and ecology as sustainability measures in water resources system [59]. The SNWDP embraces the principle of integrated infrastructure designs and operations to achieve enhanced resilience in water resources system [26,27].

However, China should also recognize the increasing threats of changing environments and associated thresholds in sustainability of water resources systems. Despite water resources reforms, both quantity and quality of water in some areas of northern China have declined [45] threatening the regional food and water security [60]. Most natural capital (forests and water) has been largely used up surpassing the benchmark of reference condition [61] (see Figure 3). For example, the extraction of 2.5 billion $\mathrm{m}^{3}$ of groundwater had deepened the ground water resource more than $1 \mathrm{~m}$ annually in some areas between 1974 and 2000 alone, showing a shift by crossing the natural reference condition [36,62] (see Table 3).



Figure 3. A sustainability framework for the water resources system in northern China. Three sustainability pillars can play the role: environmental protection; socioeconomic growth and renewable energy, and the provision of societal peace and harmony (see the text for further details). For example, in the Huang-Huai-Hai River basin, the threshold of the sustainability of water resources system (green circle in the centre) appears to have crossed the boundary. At present, water resources are determined largely by sustainable use and maintenance and development of infrastructure within the technological boundary (yellow circle). Technological boundary refers the limit of the built environment related to water resources. Ignoring this boundary will risk the collapse of the sustainability of the water resources system in northern China (red circle). 
More importantly, there are also signs of rapid recovery following the launch of the SNWDP in the east. The SNWDP has played a buffering role for restoring the surface water and groundwater systems in the region. At a critical threshold condition of water resources system, the extrinsic factors such as environmental flow, sedimentation, temperature, and chemical or nutrient loads are operating at a variety of scales. Identifying the key drivers and structural and functional responses of surface and groundwater systems on time are significant for restoration the degrading system [63]. Study suggests that further deepening of groundwater is projected to be reduced by $65 \%$ of the current level in Tianjin, Beijing and Hebei by 2023 as a result of the launch of the SNWDP $[58,62]$.

Table 3. Surface water-ground water losses in SNWDP areas over the past 30+ years: (a) total length of drying river channels over time at the lower Yellow river section; (b) Groundwater depletion over time in four different cities along the middle route of the SNWDP.

\begin{tabular}{|c|c|c|c|c|c|c|}
\hline \multicolumn{2}{|c|}{ a. Drying Channels ${ }^{a}$} & \multicolumn{5}{|c|}{ b. Buried Depth of Groundwater Table (m) } \\
\hline Year & $\mathrm{Km}(\mathrm{m})$ & Year & Handan $^{b}$ & Shijiazhuang $^{c}$ & Baoding $^{d}$ & Beijing ${ }^{e}$ \\
\hline 1991 & 131 & 2000 & 17 & 25 & 23.6 & 15.4 \\
\hline 1992 & 303 & 2001 & 19.5 & 25.8 & 21.2 & 16.4 \\
\hline 1993 & 278 & 2002 & 20.1 & 28.6 & 22.4 & 17.3 \\
\hline 1994 & 308 & 2003 & 20.5 & 29.1 & 22.4 & 18.3 \\
\hline 1995 & 683 & 2004 & 19.5 & 29.6 & 22.6 & 19 \\
\hline 1996 & 579 & 2005 & 21.5 & 31 & 22.6 & 20.2 \\
\hline 1997 & 704 & 2006 & 21.5 & 32.3 & 23.1 & 21.5 \\
\hline 1998 & 142 & 2007 & 21.8 & 33.8 & 24.6 & 22.8 \\
\hline \multirow[t]{9}{*}{1999} & 42 & 2008 & 21.8 & 34.5 & 24 & 22.9 \\
\hline & & 2009 & 22.4 & 35.1 & 26 & 24.1 \\
\hline & & 2010 & 22.5 & 35.8 & 25.4 & 24.9 \\
\hline & & 2011 & & 36.4 & 25.7 & 24.9 \\
\hline & & 2012 & & & 25 & 24.3 \\
\hline & & 2013 & & & 23.6 & 24.5 \\
\hline & & 2014 & & & 23.5 & 25.7 \\
\hline & & 2015 & & & & 25.8 \\
\hline & & 2016 & & & & 25.2 \\
\hline
\end{tabular}

a: There is no drying river channels at the lower Yellow river section after 1999. ${ }^{\text {b: }}$ average buried depth of shallow groundwater of Handan city. Data from [64]. c: average buried depth of groundwater of the plain area of Shijiazhuang city. Data from [65]. ${ }^{\mathrm{d}}$ : average buried depth of groundwater of the urban district of Baoding city. Data from [66]. e: average buried depth of groundwater of the plain area of Beijing city. Data from http://www.bjwater.gov.cn/bjwater/300747/300768/98b523d9-1.html.

It has been argued that the project will still face a critical demand for the management, which requires a long term planning by using new institutional framework of water saving such as water pricing, trade, and efficiency [67]. Despite global financial crisis causing unviable pricing and/or unforeseen costs in the maintenance of infrastructure [68], SNWDP is expected to improve water conservation, water rights and reforms and to facilitate water transfer via market mechanism, and invest wastewater treatment facilities to reclaim and reuse municipal and industrial wastewaters further [36,67]. Water markets system provides incentives for water-rights-holders with more ample supplies and relatively lower-value uses to transfer water to parties with less ample supplies and higher-value uses [69]. China has begun to adopt market-based measures to address water resource challenges in the north. Efforts are also made to encourage wastewater reuse and water conservation [70]. In Gansu Province, for example, the groundwater abstraction was estimated at $135 \%$, and irrigation accounted for $86 \%$ of basin water use prior to the 2000s. The creation of the Shiyang Basin water rights trading (WRT) system in the province has been projected to reduce consumption by 60 -million $\mathrm{m}^{3}$ annually, largely through agricultural water conservation and restricted groundwater use. Further, installation of smart meters on individual wells in the region has reduced unwanted water abstraction [70].

We argue that the current water resources demand in northern China can be addressed largely by advancing the water infrastructure technologies such as introduction of internet based water 
rights trading system [70]. Other water infrastructure projects including the enhancement of green infrastructure through catchment restoration and ecosystem management programs would also assist socioeconomic development and environmental sustainability [3]. Green infrastructure technology provides better network connectivity between natural and ecological processes and enhances community engagement for protection of ecological habitats and waterways and reduces possible crossing of 'technological boundary', the yellow circle (Figure 3). For instance, the yearly budget allocated for water pollution control infrastructure along the ERP alone is as high as 24 billion Yuan (about 3.5 billion US dollars) [71]. The SNWDP is looking at viable and durable funds for maintaining infrastructure projects such as the areas of green infrastructure in order to avoid unprecedented rise in water prices in the municipal cities including Beijing, Hebei and Tianjin [36]. However, any reduction in investments in infrastructure technology including maintenance and an inappropriate demand-supply management scheme is likely to cross the technological boundary (Figure 3). The technological boundary is the limit when the supply of water in the north is insufficient (also see the caption description in Figure 3). Under rapidly changing environment (e.g., climate change, population growth, and pollution), SNWDP should be operated within the technological boundary by advancing the environmentally friendly infrastructure. Crossing this boundary would risk a collapse of the sustainable water resources systems in the region. Advancement of innovative green infrastructure technologies coupled with improved governance has been urged to achieve the planetary goal of sustainability of water resources systems. In a planetary goal, every individual has a safe operating space for stable and sustainable environment including the use of water resources [72]. When targeting such goal, the water resources, the human appropriation and stewardship are urged to better suited for policy making of the rapidly transitioning environments [3,73].

An increased awareness of environmental, ecological and economic benefits of water for households, agriculture, energy and industries is thought to be significant at a time of regime shift of water resources [3,4]. For example, prior to MRP, the areas of the Huang-Huai-Hai River basin, were critical to shift, and fell within the red circle (Figure 3). Excessive extraction of surface and ground water together with water pollution under rapid industrial and population growth and climate change have led to surpass the green circle. The launch of SNWDP has brought back the region within the yellow circle (Figure 3), by alleviating water shortages, consequently stimulating the socioeconomic development in the region. In addition, environmental flows of the river systems have been restored, water quality of wetlands and reservoirs are improved, deepening of groundwater table has reduced and the overall socioeconomic conditions of the people in Hebei, Henan and Shandong Provinces have significantly improved [30]. The number of water-and-energy intensive industries in the region has increased employment opportunities [30]. The SNWDP is projected to generate additional $\$ 75$ billion gross domestic product (GDP) annually to 2020 significantly improving the socioeconomic conditions of people in the region further $[11,36]$. Following the launch of ERP and MRP, the projects not only have generated the GDP, they also have recharged groundwater aquifer levels, created artificial ecological corridors for better wildlife habitats, and rehabilitated of those degraded natural ecosystems in the north $[11,36]$.

Under the rapid technological advancements over the recent decades, China has also adopted the concept of "He wei gui" ("harmony is valued") for societal well-being [74,75]. Traditional belief "jun quan shen shou" ("divine right") is often considered useful in environmental governance and sustainability [76]. Today, the "peace and security" concept has been increasingly regarded for foundation of institutional security and societal goals are often embedded in the principles of good governance and sustainable water resources system [76]. The nutshell of peace and security is building a market-based economy through integration into the outside world in the process of modernization [77]. Creating a sustainable industrial structure by focusing on societal transformation with establishment of an improved social security system, ideals of fairness, justice, prosperity and harmony are considered significant [77]. 
Lately, the focus on collaborative partnerships in China have begun to address complex water issues and integrated governmental and non-governmental perspectives of water resources management in northern China. Increased dialogues and negotiation involving scientists, government stakeholders, non-profit and private sector organisations, and consultation with the public has become increasingly useful in decision making processes of water security issues [5,77]. While working for sustainable water resources strategies, one should however understand that the integrated water resource management has gradually evolved through cross-cutting 'nexus' of adaptive water governance [78,79]. Ignoring sustainable strategies adopted by SNWDP may push the water resources system in the northern drier region within the trap of the red circle (Figure 3).

\section{Conclusions}

We argue that the South-to-North Water Diversion Project will inevitably contribute to the China's water reform, environmental sustainability and socioeconomic development in the northern plains. Despite ongoing debates and complex demographic, socioeconomic and environmental challenges, SNWDP has emerged as infrastructure to accomplish sustainable water resources system including the better allocation of water resources, biological conservation and ecosystem restoration in the region successfully. Recognizing with the imminent threats of the thresholds of environmental change on time has become increasingly crucial while planning to achieve the goals for sustainable water resources system under SNWDP. A comprehensive understanding of the rapidly changing human-environment interactions, together with the monitoring and assessment of the SNWDP infrastructure, as well as the quantity and quality of water in the conveyance channel is essential for better forecasting and modelling while addressing the sustainability goals of water resources systems in northern China.

Author Contributions: G.R.K. and Z.W. developed the research idea, G.R.K. and W.S. reviewed literature and analysed the data, and G.R.K., W.S., Z.W. and J.L. together wrote the paper.

Funding: This research was funded by National Key Research Program of China Grants (\#2016YFC0402900, \#2016YFE0201900).

Acknowledgments: We would like to acknowledge the National Key Research Program of China Grants (\#2016YFC0402900, \#2016YFE0201900). We are thankful to three anonymous reviewers, whose comments have improved the quality of the manuscript significantly. GRK would also like to acknowledge the Global Talent Scholar program at Tsinghua University, Beijing.

Conflicts of Interest: The authors declare no conflict of interest.

\section{References}

1. Vörösmarty, C.J.; McIntyre, P.B.; Gessner, M.O.; Dudgeon, D.; Prusevich, A.; Green, P.; Glidden, S.; Bunn, S.E.; Sullivan, C.A.; Liermann, C.R.; et al. Global threats to human water security and river biodiversity. Nature 2010, 467, 555-561. [CrossRef] [PubMed]

2. Cosgrove, W. Water Futures: The evolution of water scenarios. Curr. Opin. Environ. Sustain. 2013, 5, 559-565. [CrossRef]

3. Kattel, G. State of future water regimes in the world's river basins: Balancing the water between society and nature. Crit. Rev. Environ. Sci. Technol. 2019, 49, 1107-1133. [CrossRef]

4. Yang, H.; Zehnder, A.J.B. The South-North Water Transfer Project in China. Water Int. 2005, 30, 339-349. [CrossRef]

5. Liu, J.; Yang, W. Water sustainability for China and beyond. Science 2012, 337, 649-650. [CrossRef] [PubMed]

6. Xu, Y.; Li, S.; Cai, Y.; Li, X. Land use and groundwater use in Hebei Plain China. Water Environ. J. 2005, 19, 109-114. [CrossRef]

7. Zhao, Y.; Zhu, Y.; Lin, Z.; Wang, J.; He, G.; Li, H.; Li, L.; Wang, H.; Jiang, S.; He, F.; et al. Energy Reduction Effect of the South-to-North Water Diversion Project in China. Sci. Rep. 2017, 7, 15956. [CrossRef] [PubMed]

8. Currell, M.J.; Han, D.; Chen, Z.; Cartwright, I. Sustainability of groundwater usage in northern China: Dependence on palaeowaters and effects on water quality, quantity and ecosystem health. Hydrol. Process. 2012, 26, 4050-4066. [CrossRef] 
9. Miao, C.; Ni, J.; Borthwick, A.G.L.; Yang, L. A preliminary estimate of human and natural contributions to the changes in water discharge and sediment load in the Yellow River. Glob. Planet. Chang. 2011, 76, 196-205. [CrossRef]

10. Liu, C.; Xia, J. Water problems and hydrological research in the Yellow River and the Huai and Hai River basins of China. Hydrol. Process. 2004, 18, 2197-2210. [CrossRef]

11. SNWDP (South-to-North Water Diversion Project). The South-to-North Water Diversion Project. Engineering 2016, 2, 265-267. [CrossRef]

12. Kates, R.W.; Parris, T.M. Long-term trends and a sustainability transition. Proc. Natl. Acad. Sci. USA 2003, 100, 8062-8067. [CrossRef] [PubMed]

13. Clark, W.C.; Dickson, N.M. Sustainability science: The emerging research program. Proc. Natl. Acad. Sci. USA 2003, 100, 8059-8061. [CrossRef] [PubMed]

14. Stillwell, A.S. Sustainability of public policy: Example from the energy-water nexus. J. Water Resour. Plan. Manag. 2015, 141, 1-7. [CrossRef]

15. Bhattacharya, A.; Meltzer, J.P.; Oppenheim, J.; Qureshi, Z.; Stern, N. Delivering on Sustainable Infrastructure for Better Development and Better Climate; The Brooking Institutions: New York, NY, USA, 2016.

16. Turner, B.L., II; Kasperson, R.E.; Matson, P.A.; McCarthy, J.J.; Corell, R.W.; Christensen, L.; Eckley, N.; Kasperson, J.X.; Luers, A.; Martello, M.L.; et al. A framework for vulnerability analysis in sustainability science. Proc. Natl. Acad. Sci. USA 2003, 100, 8074-8079. [CrossRef] [PubMed]

17. Vanegas, J.A. Road map and principles for built environment sustainability. Environ. Sci. Technol. 2003, 37, 5363-5372. [CrossRef] [PubMed]

18. Ruiters, C. Funding models for financing water infrastructure in South Africa: Framework and critical analysis of alternatives. Water SA 2013, 39, 313-326. [CrossRef]

19. Sheng, J.; Webber, M. Incentive-compatible payments for watershed services along the Eastern Route of China's South-North Water Transfer Project. Ecosyst. Serv. 2017, 25, 213-226. [CrossRef]

20. Poff, N.L.; Brown, C.M.; Grantham, T.E.; Matthews, J.H.; Palmer, M.A.; Spence, C.M.; Wilby, R.L.; Haasnoot, M.; Mendoza, G.F.; Dominique, K.C.; et al. Sustainable water management under future uncertainty with eco-engineering decision scaling. Nat. Clim. Chang. 2015, 6, 25-34. [CrossRef]

21. Tang, C.; Yi, Y.; Yang, Z.; Sun, J. Risk forecasting of pollution accidents based on an integrated Bayesian Network and water quality model for the South to North Water Transfer Project. Ecol. Eng. 2016, 96, 109-116. [CrossRef]

22. Li, S.; Li, J.; Zhang, Q. Water quality assessment in the rivers along the water conveyance system of the Middle Route of the South to North Water Transfer Project (China) using multivariate statistical techniques and receptor modeling. J. Hazard. Mater. 2011, 195, 306-317. [CrossRef] [PubMed]

23. Yaseen, Z.M.; Sulaiman, S.O.; Deo, R.C.; Chau, K.-W. An enhanced extreme learning machine model for river flow forecasting: State-of-the-art, practical applications in water resource engineering area and future research direction. J. Hydrol. 2019, 569, 387-408. [CrossRef]

24. Jiang, X.; Liu, C. The influence of water regulation on vegetation in the lower Heihe River. J. Geogr. Sci. 2010, 20,701-711. [CrossRef]

25. Wei, D. Beijing water resources and the south to north water diversion project. Can. J. Civ. Eng. 2005, 32, 159-163. [CrossRef]

26. SNWDPCCO (South-to-North Water Diversion Project). Bidding Announcement for the Survey and Design of the Xiheishan Hydropower Station on the Middle Route of SNWDP. Available online: http: //www.nsbd.gov.cn/zw/zqxx/jsgl/6/201604/t20160415_438917.html (accessed on 11 April 2019).

27. SNWDPCCO (South-to-North Water Diversion Project). Practice of Cutting down Groundwater Exploitation in Beijing. Available online: http://www.nsbd.gov.cn/zx/rdht/201601/t20160113_434644.html (accessed on 11 April 2019).

28. Liu, J.; Raven, P.H. China's Environmental Challenges and Implications for the World. Crit. Rev. Environ. Sci. Technol. 2010, 40, 823-851. [CrossRef]

29. Wu, K.; Yuan, Z.; Lu, B. Agricultural resources, the eco-environment and the economic benefit in the South-to-North Water Diversion. South North Water Transf. Water Sci. Technol. 2006, 4, 4-7.

30. IWA (International Water Association). China's Water Diversion Project Replenishes 30 Rivers. Available online: https://www.thesourcemagazine.org/chinas-water-diversion-project-replenishes-30-rivers/ (accessed on 11 April 2019). 
31. Global-Times Biggest Water Transfer Project Ever Benefits 100 Million in China. Available online: http: //www.globaltimes.cn/content/1052749.shtml (accessed on 11 April 2019).

32. Xu, X.-Z.; Song, G.-D.; Dang, T.-M.; Liu, J.-W.; Zhang, H.-W.; Gao, H.; Liu, Y.-K. Environment and sustainability of the Middle Route, South-to-North Water Transfer Project in China: A close look. Environ. Dev. Sustain. 2017, 20, 2415-2426. [CrossRef]

33. Nabavi-Pelesaraei, A.; Rafiee, S.; Mohtasebi, S.S.; Hosseinzadeh-Bandbafha, H.; Chau, K.-W. Comprehensive model of energy, environmental impacts and economic in rice milling factories by coupling adaptive neuro-fuzzy inference system and life cycle assessment. J. Clean. Prod. 2019, 217, 742-756. [CrossRef]

34. Jiang, Y.; Chen, Y.; Younos, T.; Huang, H.; He, J. Urban sater resources quota management: The core strategy for water demand management in China. Ambio 2010, 39, 467-475. [CrossRef] [PubMed]

35. Nosratabadi, S.; Mosavi, A.; Shamshirband, S.; Kazimieras Zavadskas, E.; Rakotonirainy, A.; Chau, K.W. Sustainable Business Models: A Review. Sustainability 2019, 11, 1663. [CrossRef]

36. He, C.; He, X.; Fu, L. China's South-to-North Water Transfer Project: Is it needed? Geogr. Compass 2010, 4, 1312-1323. [CrossRef]

37. MWR (Morale, Welfare and Recreation). China Water Resources Report. Available online: http://www.mwr. gov.cn/zwzc/hygb/szygb/qgszygb/201212/t20121217_335297.html (accessed on 11 April 2019).

38. Berkoff, J. China: The South-North Water Transfer Project-is it justified? Water Policy 2003, 5, 1-28. [CrossRef]

39. Zhou, Y.; Tol, R.S.J. Implications of desalination for water resources in China an economic perspective. Desalination 2004, 164, 225-240. [CrossRef]

40. Zhang, Q.; Xu, Z.; Shen, Z.; Li, S.; Wang, S. The Han River watershed management initiative for the South-to-North Water Transfer project (Middle Route) of China. Environ. Monit. Assess. 2009, 148, 369-377. [CrossRef] [PubMed]

41. Chen, H.-C.; Du, P. Potential ecological benefits of the Middle Route for the South-North Water Diversion Project. Tsinghua Sci. Technol. 2008, 13, 715-719. [CrossRef]

42. Vina, A.; McConnell, W.J.; Yang, H.; Xu, Z.; Liu, J. Effects of conservation policy on China's forest recovery. Sci. Adv. 2016, 2, 1-7. [CrossRef]

43. Florig, K.H.; Spofford, W.O., Jr.; Ma, X.; Ma, Z.G. China strives to make the polluter pay. Environ. Sci. Technol. 1995, 29, 268A-273A. [CrossRef]

44. Liu, J.; Diamond, J. China's environment in the globalising world. Nature 2005, 435, 1179. [CrossRef]

45. Jiang, Y. China's water scarcity. J. Environ. Manag. 2009, 90, 3185-3196. [CrossRef]

46. Yi, L.; Jiao, W.; Chen, X.; Chen, W. An overview of reclaimed water reuse in China. J. Environ. Sci. 2011, 23, 1585-1593. [CrossRef]

47. Yang, Y.; Yin, L.; Zhang, Q. Quantity versus quality in China's South-to-North Water Diversion Project: A system dynamics analysis. Water 2015, 7, 2142-2160. [CrossRef]

48. Barnett, J. Transfer project cannot meet China's water needs. Nature 2015, 527, 295-297. [CrossRef] [PubMed]

49. Bawa, K. China, India, and the Environment. Science 2010, 327, 1557-1559. [CrossRef] [PubMed]

50. Moore, S.M. Modernisation, authoritarianism, and the environment: The politics of China's South-North Water Transfer Project. Environ. Politics 2014, 23, 947-964. [CrossRef]

51. Howells, M.; Hermann, S.; Welsch, M.; Bazilian, M.; Segerström, R.; Alfstad, T.; Gielen, D.; Rogner, H.; Fischer, G.; van Velthuizen, H.; et al. Integrated analysis of climate change, land-use, energy and water strategies. Nat. Clim. Chang. 2013, 3, 621-626. [CrossRef]

52. Lu, Z.; Ma, X.; Sang, W.; Fan, Y. Ecological benefit assessment of the South-North Water Transfer Project: An eastern route. Int. J. Sustain. Dev. World Ecol. 2010, 13, 221-227. [CrossRef]

53. Westley, F.; Olsson, P.; Folke, C.; Homer-Dixon, T.; Vredenburg, H.; Loorbach, D.; Thompson, J.; Nilsson, M.; Lambin, E.; Sendzimir, J.; et al. Tipping Toward Sustainability: Emerging Pathways of Transformation. Ambio 2011, 40, 762-780. [CrossRef]

54. Sahely, H.R.; Kennedy, C.A.; Adams, B.J. Developing sustainability criteria for urban infrastructure systems. Can. J. Civ. Eng. 2005, 32, 72-85. [CrossRef]

55. Zhou, J.; Erdal, Z.K.; McCreanor, P.T.; Montalto, F. Sustainability. Water Environ. Res. 2010, 82, $1376-1395$. [CrossRef]

56. Lu, Y.; Jenkins, A.; Ferrier, C.; Bailey, M.; Gordon, I.J.; Song, S.; Huang, J.; Jia, S.; Zhang, F.; Liu, X.; et al. Addressing China's grand challenge of achieving food security while ensuring environmental sustainability. Sci. Adv. 2015, 1, e1400039. [CrossRef] 
57. Feng, S.; Li, L.X.; Duan, Z.G.; Zhang, J.L. Assessing the impacts of South-to-North Water Transfer Project with decision support systems. Decis. Support Syst. 2007, 42, 1989-2003. [CrossRef]

58. Thomé, A.M.T.; Ceryno, P.S.; Scavarda, A.; Remmen, A. Sustainable infrastructure: A review and a research agenda. J. Environ. Manag. 2016, 184, 143-156. [CrossRef] [PubMed]

59. Brown, L.R.; Halweil, B. China's water shortage could shake world food security. World Watch 1998, 11, 10-18. [PubMed]

60. Zhang, K.; Dearing, J.A.; Tong, S.L.; Hughes, T.P. China's Degraded Environment Enters A New Normal. Trends Ecol. Evol. 2016, 31, 175-177. [CrossRef] [PubMed]

61. Qiu, J. China faces up to groundwater crisis. Nature 2010, 466, 308. [CrossRef] [PubMed]

62. Groffman, P.M.; Baron, J.S.; Blett, T.; Gold, A.J.; Goodman, I.; Gunderson, L.H.; Levinson, B.M.; Palmer, M.A.; Paerl, H.W.; Peterson, G.D.; et al. Ecological Thresholds: The Key to Successful Environmental Management or an Important Concept with No Practical Application? Ecosystems 2006, 9, 1-13. [CrossRef]

63. Fu, D. Dynamic Characteristics of Groundwater Level in Handan, Hebei Plain Area; Shijiazhuang University of Economics: Shijiazhuang, China, 2013.

64. Li, Y.; Li, S.; Zhou, H.; Liang, Y. Groundwater dynamic evolution analysis of Shijiazhuang Plain. Water Sci. Eng. Technol. 2012, 1, 11-13.

65. Wang, Q. The Study of Groundwater Depth Prediction Methods in Baoding City; China University of Geosciences: Beijing, China, 2016.

66. Chen, Z.; Wang, H.; Qi, X. Pricing and water resource allocation scheme for the South-to-North Water Diversion Project in China. Water Resour. Manag. 2013, 27, 1457-1472. [CrossRef]

67. Hukka, J.J.; Katko, T.S. Appropriate pricing policy needed worldwide for improving water services infrastructure. J. Am. Water Work. Assoc. 2015, 107, E37-E46. [CrossRef]

68. Hanak, E.; Lund, J.R. Adapting California's water management to climate change. Clim. Chang. 2011, 111, 17-44. [CrossRef]

69. Moore, S.M. The development of water markets in China: Progress, peril, and prospects. Water Policy 2015, 17, 253-267. [CrossRef]

70. CAEP (Canadian Association of Emergency Physicians). Introduction of the water pollution control plan of the South-to-North Water Diversion Project. China Water Resour. 2003, 2, 19-22.

71. Steffen, W.; Richardson, K.; Rockström, J.; Cornell, S.E.; Fetzer, I.; Bennett, E.M.; Biggs, R.; Carpenter, S.R.; de Vries, W.; de Wit, C.A.; et al. Sustainability. Planetary boundaries: Guiding human development on a changing planet. Science 2015, 347, 1259855. [CrossRef] [PubMed]

72. Bogardi, J.J.; Fekete, B.M.; Vörösmarty, C.J. Planetary boundaries revisited: A view through the 'water lens'. Curr. Opin. Environ. Sustain. 2013, 5, 581-589. [CrossRef]

73. Delury, J. Harmoneous in China. Policy Rev. 2008, 148, 35.

74. Ip, P.-K. Harmony as happiness? social harmony in two Chinese societies. Soc. Indic. Res. 2013, 117, 719-741. [CrossRef]

75. Li, Y.; Cheng, H.; Beeton, R.J.S.; Sigler, T.; Halog, A. Sustainability from a Chinese cultural perspective: The implications of harmonious development in environmental management. Environ. Dev. Sustain. 2015, 18, 679-696. [CrossRef]

76. Liru, C. Peaceful Rise: China's Modernisation Trajectory. Int. Spect. 2012, 47, 14-17. [CrossRef]

77. Sun, F.; Staddon, C.; Chen, M. Developing and applying water security metrics in China: Experience and challenges. Curr. Opin. Environ. Sustain. 2016, 21, 29-36. [CrossRef]

78. Gupta, J.; Pahl-Wostl, C.; Zondervan, R. 'Global' water governance: A multi-level challenge in the anthropocene. Curr. Opin. Environ. Sustain. 2013, 5, 573-580. [CrossRef]

79. Al-Saidi, M.; Elagib, N.A. Towards understanding the integrative approach of the water, energy and food nexus. Sci. Total Environ. 2017, 574, 1131-1139. [CrossRef] [PubMed]

(C) 2019 by the authors. Licensee MDPI, Basel, Switzerland. This article is an open access article distributed under the terms and conditions of the Creative Commons Attribution (CC BY) license (http://creativecommons.org/licenses/by/4.0/). 